\title{
PEMBUATAN SABUN CUCI TANGAN SEBAGAI UPAYA PEMUTUSAN PENYEBARAN RANTAI COVID - 19 DI KABUPATEN TUBAN
}

\author{
Oleh: \\ Nuniek Herdyastuti ${ }^{1}$, Titik Taufikurrohmah ${ }^{1}$, Rusmini ${ }^{1}$, Mustaji2, Sari Edi Cahyaningrum ${ }^{1}$ \\ 1Jurusan Kimia FMIPA Universitas Negeri Surabaya \\ ${ }^{1}$ nuniekherdyastuti@unesa.ac.id
}

Virus Corona ini telah melanda sekitar 152 negara di dunia yang tersebar di semua benua termasuk negara Indonesia. Propinsi Jawa Timur menempati urutan tertinggi jumlah positip Covid 19 dan dikategorikan dalam zona merah di 32 kota dan kabupaten termasuk Tuban. Pencegahan penyebaran virus corona dapat dilakukan dengan cara menjaga jarak aman, menggunakan masker dan mencuci tangan dengan air mengalir atau menggunakan sabun. Sabun cuci tangan mengandung bahan antiseptic yang dapat membunuh virus. Universitas Negeri Surabaya mempunyai potensi dosen-dosen yang mempunyai kemampuan untuk membuat sabun cuci tangan. Kegiatan ini bertujuan untuk membuat sabun cuci tangan untuk memutus rantai penyebaran Covid 19 khususnya di Kabupaten Tuban. Telah berhasil memproduksi sabun cuci tangan kemasan $500 \mathrm{~mL}$ sebanyak 500 buah dan telah diserahkan ke Kabupaten Tuban melalui Unit Crisis Center Unesa. Bantuan diterima oleh Bupati Tuban dan didistribusikan ke masyarakat Tuban yang membutuhkan.

Kata Kunci: sabun cuci tangan, Covid-19, Tuban

\begin{abstract}
This Corona virus has hit around 152 countries in the world, spread across all continents including Indonesia. East Java Province ranks the highest number of positive Covid 19 and is categorized in the red zone in 32 cities and districts including Tuban. Prevention of the spread of the corona virus can be done by maintaining a safe distance, using a mask and washing hands with running water or using soap. Hand soap contains antiseptic properties that can kill viruses. Surabaya State University has the potential for lecturers who have the ability to make hand washing soap. This activity aims to make hand soap to break the chain of spreading Covid 19, especially in Tuban Regency. It has succeeded in producing $500 \mathrm{~mL}$ of hand washing soap in $500 \mathrm{~mL}$ packages and has been submitted to Tuban Regency through the Unesa Crisis Center Unit. The assistance was received by the Regent of Tuban and distributed to the people of Tuban in need.
\end{abstract}

Keywords: handsoap, Covid-19, Tuban

\section{PENDAHULUAN}

Penduduk di muka bumi pada awal tahun 2020 ini diguncang dengan kemunculan wabah yang disebabkan oleh virus Corona yang akhir-akhir ini menjadi bahan perbincangan semua orang. Virus Corona 2019 atau nCov 2019 atau lebih dikenal sebagai Covid-19 ini pertama kali ditemukan di Wuhan salah satu kota di China. Simpang siur kabar soal sumber kemunculan virus ini, mulai dari makanan hingga hewanhewan unggas. Hal ini dikarenakan belum adanya informasi yang jelas soal asal muasal kemunculan virus tersebut pada saat itu.
Virus ini mudah sekali menyebar, Komisi Kesehatan Nasional China mengkonfirmasi virus corona dapat ditularkan dari manusia ke manusia yang terinfeksi. Bahkan virus itu bisa saja menempel di salah satu tempat dekat pasien corona.

Global cases by John Hopkins CSSE menyebutkan bahwa virus Corona ini telah melanda sekitar 152 negara di dunia yang tersebar di semua benua termasuk negara Indonesia. Angka kasus infeksi virus corona penyebab Covid-19 di Indonesia terus bertambah setelah satu bulan sejak laporan pertama virus corona di Indonesia pada 2 Maret 2020. Pada awal bulan April dilaporkan bahwa di Indonesia terdapat tambahan 
sebanyak 149 kasus baru, sehingga totalnya 1677 kasus. Pasien sembuh diketahui bertambah 22 orang menjadi 103, dan kasus kematian menjadi 157 orang setelah adanya tambahan 22 kasus. (https://www.kompas. com/tren/read/2020/04/02/054700165/update -virus-corona-di-indonesia-rincian-kasuscovid-19-di-32-provinsi).

Jumlah tersebut telah bertambah sangat luar biasa pada 2 bulan terakhir ini, dimana pada tanggal 10 Agustus tercatat 127.083 kasus yang tersebuar di 34 provinsi, terkonfirmasi dengan pertambahan setiap harinya lebih dari 1000 orang dan sebanyak 5765 orang yang meninggal (https://palu.tribunnews.com/2020/08/10/seba ran-covid-19-indonesia). DKI Jakarta, Jawa Barat, dan Jawa Timur merupakan tiga propinsi yang menempati urutan tertinggi jumlah penduduk yang terpapar positive Corona di Indonesia.

Jawa Timur merupakan provinsi yang menempati urutan kedua setelah DKI Jakarta untuk kasus Corona tersebut, dan bahkan sempat menempati urutan pertama pada bulan Juli sehingga mendapat perhatian dari Pemerintah Indonesia. Pada tanggal 10 Agustus tercatat 25.626 orang yang positif, tetapi total pasien sembuh cukup tinggi yaitu 18.417 orang. Di Jawa Timur terdapat 27 klaster penyebaran Covid 19 dan dikategorikan dalam zona merah di 32 kota (Gambar 1) dan kabupaten dan salah satu diantaranya adalah Tuban.

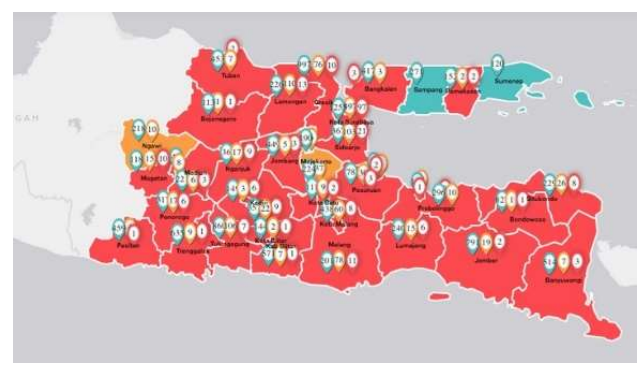

Gambar 1. Peta sebaran Covid 19 di Jawa Timur

Tuban sebelumnya berstatus Keadaan Tertentu Darurat Bencana Infeksi Covid19, namun saat ini statusnya resmi ditetapkan menjadi Keadaan Darurat bersama 19 kabupaten dan kota se Jawa Timur. Di kabupaten Tuban terdapat 2 warganya yang dinyatakan positif terjangkit virus yang sedang mendunia tersebut dengan peta sebaran seperti pada Gambar 2. Satu orang masih menjalani perawatan medis, seorang lainnya meninggal dunia. Data ini menambah daftar semakin meluasnya Pandemi Covid-19 di Jawa Timur. Pada hari yang sama kepada seputartuban.com Bupati Tuban, Fathul Huda menghimbau kepada masyarakat atas perubahan kondisi Tuban menjadi zona merah agar selalu mematuhi ketentuan yang telah dikeluarkan pemerintah, serta meningkatkan pendekatan diri kepada Tuhan.

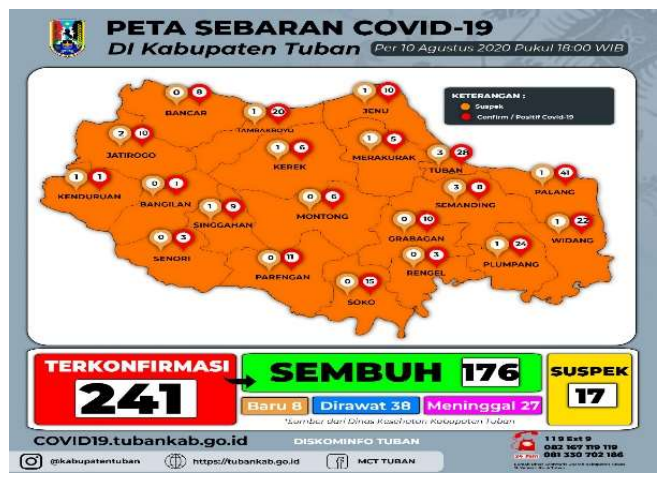

Gambar 2. Peta sebaran Covid - 19 di Kabupaten Tuban yang telah menjadi zona orange pada bulan Agustus

Virus corona dapat ditularkan melalui beberapa cara, yaitu : (i) Tidak sengaja menghirup percikan ludah dari bersin atau batuk penderita virus Corona, (ii) Memegang mulut atau hidung tanpa mencuci tangan terlebih dulu, setelah menyentuh benda yang terkena air liur penderita. (iii) Kontak jarak dekat dengan penderita, seperti bersentuhan atau berjabat tangan. Berdasarkan penelitian disebutkan bahwa virus Corona dapat menginfeksi siapa saja, tetapi lebih berisiko menyerang orang tua, serta orang yang sedang sakit atau memiliki kekebalan tubuh lemah. Sehingga pemerintah menyarankan untuk melakukan kegiatan belajar, bekerja, beribadah di rumah atau yang dikenal dengan WFH (work from home) sebagai upaya untuk memutus rantai penyebaran Covid. Tindakan pertama yang dapat dilakukan untuk menangkal virus corona adalah dengan rajin mencuci tangan. Sebab, tangan adalah salah satu anggota tubuh yang menjadi sumber penyakit. Cuci tangan dengan durasi minimal 20 detik dapat untuk membunuh virus corona menggunakan sabun dan air bersih yang 
mengalir. Tindakan pencegahan yang satu ini dianggap lebih efektif untuk membunuh kuman, bakteri, termasuk virus corona. Cuci tangan merupakan langkah yang disarankan oleh banyak pihak, termasuk Organisasi Kesehatan Dunia. Seorang ahli virus Dr John Williams yang merupakan kepala divisi penyakit menular anak-anak di Rumah Sakit Anak, Pittsburg University Center Medical, Pittsburgh menyatakan bahwa virus Corona ditutupi dengan "menara runcing" seperti mahkota sehingga disebut sebagai Corona. Di bawah mahkota terdapat lapisan luar yang komposisinya merupakan suatu lemak. Adanya sabun atau alkohol dapat melarutkan lemak dan memecah ikatan-ikatan lemah yang ada di dalamnya sehingga dapat membunuh virus tersebut (https://palu.tribunnews.com

/2020/03/25/bagaimana-cara-kerja-sabunhand-sanitizer-mencegah-penyebaran-viruscorona). Penjelasan tersebut merupakan dasar mengapa kita perlu melakukan kegiatan cuci tangan sesering mungkin.

Sabun cuci tangan atau sabun cair pembersih tangan merupakan sabun untuk pembersih dibuat menggunakan proses saponifikasi menggunakan penambahan zat lain ataupun tanpa penambahan zat lain yang tidak menimbulkan iritasi kulit tangan (Kusumayanti dkk, 2018). Sabun adalah bahan yang berasal dari minyak alami atau lemak bereaksi dengan soda kaustik dalam prosesnya dikenal sebagai reaksi penyabunan atau saponifikasi. Manfaat sabun sebagai bahan pembersih berkaitan dengan sifat surfaktan yang terkandung didalamnya. Surfaktan adalah molekul yang memiliki gugus polar yang suka air (hidrofilik) sekaligus gugus non polar yang suka lemak/minyak (lipofilik), sehingga kedua gugus tersebut dapat mempersatukan campuran yang mengandung minyak dan air untuk dapat dihilangkan dengan air.

\section{METODE}

Metode yang digunakan dalam kegiatan PKM ini adalah pelatihan dan sosialisasi serta praktek untuk identifikasi terkait makanan yang sehat dan halal.

\section{Sasaran kegiatan \\ Sasaran kegiatan pelatihan adalah Pemerintah Kabupaten Tuban}

2. Tempat Kegiatan

Tempat kegiatan adalah di Kabupaten Tuban

\section{Prosedur Pelaksanaan}

Kegiatan pelatihan ini terdiri dari beberapa tahap yaitu ;

1. Studi pendahuluan. Studi pendahuluan dilakukan dalam rangka untuk mengetahui kondisi di Kabupaten Tuban sebagai salah satu zona merah penyebaran Covid 19, dan menentukan tempat-tempat yang akan dijadikan tujuan pemberian produk sabun cuci tangan. Direncanakan akan dilakukan distribusi sabun cuci tangan pada tempat yang memegang peranan penting seperti puskesmas, pondok pesantren, masjid, dan radio sebagai media partner

2. Pembuatan sabun cuci tangan. Sabun cuci tangan dibuat oleh dosen-dosen Unesa dalam bentuk sabun cair. Sabun cuci tangan tersebut dikemas dalam bentuk botol dengan volume masingmasing $500 \mathrm{~mL}$.

3. Metode Pendekatan. Metode penedekatan untuk melakukan distribusi dan memberikan pengertian kepada masyarakat sehingga peduli terhadap pandemi Covid 19 ini adalah melalui pemuka agama atau instansi yang berpengaruh di masyarakat. Beberapa oarng yang dianggap penting dan berpengaruh adalah seperti ketua pondok pesantren, takmir masjid ataupun petugas kesehatan dan juga melalui media seperti radio sehingga dapat membantu memberikan pengarahan kepada masyarakat.

4. Partisipasi Masyarakat. Program ini tidak akan berjalan dengan baik tanpa adanya dukungan dari masyarakat, sehingga perlu ada upaya untuk melibatkan masyarakat yang ada di Kabupaten Tuban. Melalui jaringan orang-orang terdekat di tingkat RT, RW atau Kelurahan maka diupayakan sosialisasikan aktivitas gerakan cuci tangan

5. Evaluasi. Tahap ini dilakukan mengetahui bagaimana hasil yang telah diperoleh terkait distribusi sabun cuci tangan dan aktivitas cuci tangan masyarakat melalui laporan dari RT, RW ataupun Kelurahan.

\section{HASIL DAN PEMBAHASAN}

\section{Pembuatan Sabun Cuci Tangan}

Gerakan mencuci tangan pada masa pandemic saat ini telah menjadi suatu kebiasaan bagi masyarakat di sekitar kita, meskipun sebenarnya kesadaran perilaku sehat ini telah dilaksanakan pada akhir abad ke 19 . Pada saat ini masyarakat dianjurkan 
untuk berperilaku hidup sehat supaya terhindar dari virus yang banyak menyebabkan kematian di seluruh belahan dunia. Mencuci tangan dengan sabun sangat dianjurkan sekali setiap kita selesai beraktivitas, dan Gerakan ini telah dilaksanakan di instansi, layanan public, perkampungan dan lain-lain. Segala jenis sabun dapat digunakan untuk mencuci tangan baik itu sabun mandi biasa, sabun antiseptik, ataupun sabun cair. Namun sabun antiseptic atau anti bakteri sering kali dipromosikan lebih banyak pada publik. Hingga kini tidak ada penelitian yang dapat membuktikan bahwa sabun antiseptik atau disinfektan tertentu dapat membuat seseorang rentan pada organisme umum yang berada di alam (Weber, 2006). Mencuci tangan dengan sabun adalah salah satu cara paling efektif untuk mencegah penyakit diare dan ISPA, yang keduanya menjadi penyebab utama kematian anakanak. Setiap tahun, sebanyak 3,5 juta anak-anak diseluruh dunia meninggal sebelum mencapai umur lima tahun karena penyakit diare dan ISPA. Mencuci tangan dengan sabun juga dapat mencegah infeksi kulit. Perbedaan antara sabun antiseptik dan sabun biasa adalah, sabun ini mengandung zat anti bakteri umum seperti Triklosan yang memiliki daftar panjang akan resistensinya terhadap organisme tertentu.

Sabun cuci tangan atau sabun cair pembersih tangan merupakan sabun untuk pembersih yang dibuat dengan menggunakan proses saponifikasi menggunakan penambahan zat lain ataupun tanpa penambahan zat lain yang tidak menimbulkan iritasi kulit tangan (Kusumayanti dkk, 2018). Sabun adalah bahan yang berasal dari minyak alami atau lemak bereaksi dengan soda kaustik dalam prosesnya dikenal sebagai reaksi penyabunan atau saponifikasi. Manfaat sabun sebagai bahan pembersih berkaitan dengan sifat surfaktan yang terkandung didalamnya. Surfaktan adalah molekul yang memiliki gugus polar yang suka air (hidrofilik) sekaligus gugus non polar yang suka lemak/minyak (lipofilik), sehingga kedua gugus tersebut dapat mempersatukan campuran yang mengandung minyak dan air untuk dapat dihilangkan dengan air. Adapun komposisi dari sabun cuci tangan dalam bentuk cair ini adalah : Natrium klorida, texaphone, foam booster-CKD, asam karboksilat, dewisil liquid, trilon (EDTA), aquades, pewarna dan parfum. Semua bahan-bahan tersebut ditimbang sesuai dengan prosedur yang ada kemudian dicampur sampai rata dan ditambahkan pewarna serta parfum sesuai dengan selera. Sabun cair tersebut dapat ditambahkan antibakteri apabila dikehendaki. Sabun yang telah jadi tersebut kemudian dimasukkan dalam botol-botol dengan volume $500 \mathrm{~mL}$ seperti pada Gambar 1

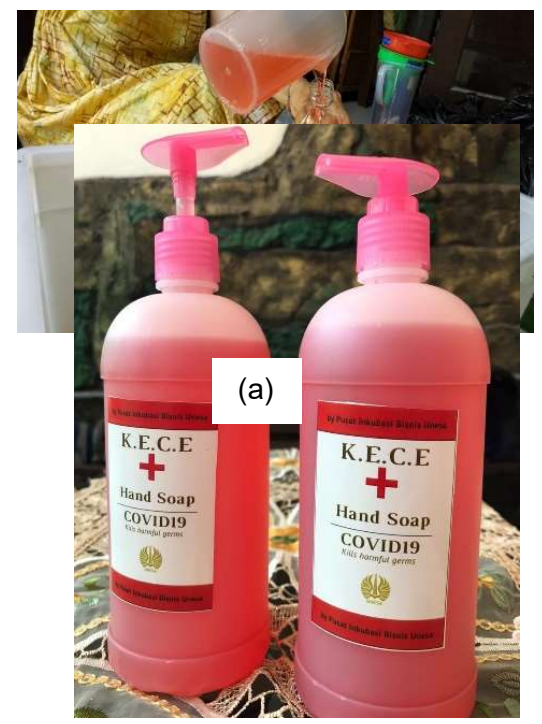

(b)

Gambar 1. Sabun cuci tangan yang telah dihasilkan pada kegiatan PKM dimulai dari pembuatan (a) dan pengemasan (b)

\section{Penyerahan produk ke Kabupaten Tuban \\ Kegiatan Pengabdian Kepada} Masyarakat ini secara khusus diperuntukkan bagi penanganan Covid 19 sebagai bukti kepedulian civitas akademik Universitas Negeri Surabaya akibat adanya pandemic yang melanda semua belahan Negara termasuk Indonesia. Penyaluran sabun cuci tangan tersebut ke Kabupaten Tuban dilakukan secara bersamaan dengan beberapa bantuan lainnya melalui Unit Crisis Center (UCC) Unesa.

Berdasarkan data sebaran Covid-19 Pemeritah Provinsi Jawa Timur, Kabupaten Tuban merupakan salah satu wilayah yang tergolong zona merah pandemic Covid - 19 
pada bulan Juni - Juli. Akan tetapi data pada 8 Agustus menyebutkan bahwa Tuban tergolong dalam zona orange bersama dengan 25 daerah lainnya atau sekitar $65,79 \%$

(https://www.merdeka.com/peristiwa/sembilan -daerah-di-jawa-timur-masih-zona-merah-

covid-19.html ). Peta penyebaran Covid - 19 di Kabupaten Tuban seperti pada Gambar 2. Pemerintah Kabupaten Tuban bertekat untuk terus berusaha memutus penyebaran virus Corona atau Covid-19 di wilayahnya. Disampaikan Kepala Dinas Kesehatan Kabupaten Tuban, bahwa Pemerintah Kabupaten Tuban menargetkan pada bulan Agustus 2020 telah menjadi zona kuning (https://surabaya.tribunnews.com/2020/07/24/

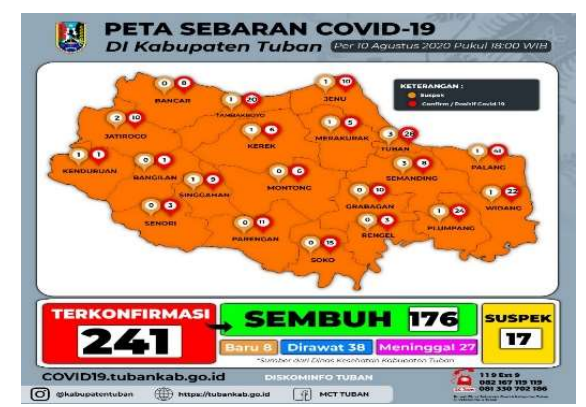

pemkab-tuban-targetkan-wilayahnya-jadizona-kuning-pada-agustus-2020).

Gambar 2. Peta sebaran Covid - 19 di Kabupaten Tuban yang telah menjadi zona orange pada bulan Agustus

Sebagai salah satu upaya untuk membantu kondisi yang ada di Kabupaten tersebut, maka Unesa melalui kegiatan pengabdian kepada masyarakat menyalurkan berbagai produk, salah satunya adalah sabun cuci tangan. Penyaluran bantuan tersebut telah dikoordinasi melalui UCC - Unesa kemudian menyerahkan kepada Bupati Tuban Fathul Huda (Gambar 3). Bantuan tersebut diharapkan dapat membantu memutus rantai penyebaran Covid - 19 dengan membiasakan cuci tangan setiap selesai melakukan aktivitas. UCC - Unesa menyerahkan sepenuhnya kepada Pemerintah Kabupaten Tuban untuk mendistribusikan bantuan yang telah diberikan karena Pemerintah Kabupaten Tuban lebih memahami kondisi wilayahnya. Pada saat pengiriman bantuan tersebut Kabupaten Tuban masih berada pada zona merah, dengan berjalannya waktu selama kurang lebih satu bulan, Tuban telah berhasil mengatasi pandemic dengan berada pada zona orange. Seperti yang telah disebutkan di atas, Pemerintah Kabupaten Tuban telah bertekat untuk menurunkan menjadi zona kuning pada bulan Agustus dan zona hijau pada bulan Nopember mendatang. Semoga hal kecil yang telah dilakukan oleh Universitas Negeri Surabaya memberikan dampak yang berarti bagi Kabupaten Tuban, khusunya terhadap pemutusan rantai penyebaran Covid - 19 serta daerah-daerah lainnya sehingga Indonesia segera terbebas dari wabah pandemic ini.
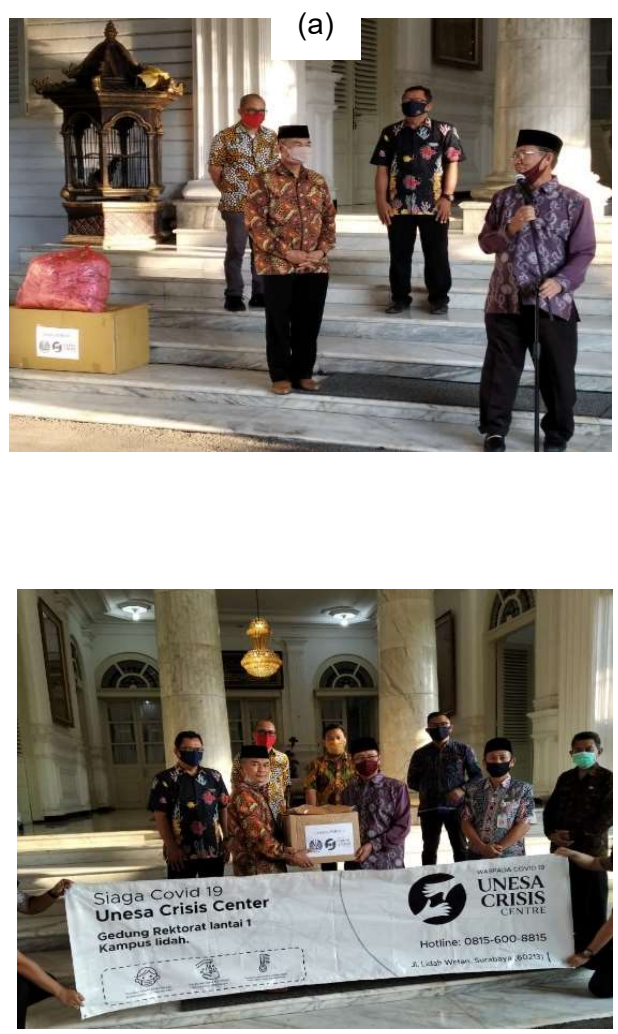
(b)

Gambar 3. Penyerahan bantuan terkait Covid - 19 di Kabupaten Tuban yang diterima oleh Bupati Tuban Bapak Fathul Huda (a) oleh tim UCC Unesa (b)

\section{SIMPULAN DAN SARAN}

Sabun cuci tangan yang telah dibuat oleh dosen Unesa telah berhasil didistribusikan ke Kabupaten Tuban sebagai salah satu zona merah Corona. Distribusi di kabupaten tuban dilakukan melalui Unit crisis center Unesa dan telah diterima oleh Bupati Tuban.

\section{DAFTAR PUSTAKA}

https://www.kompas.com/tren/read/2020/04/0 2/054700165/update-virus-corona-diindonesia-rincian-kasus-covid-19-di32-provinsi diakses tanggal 13 April $\underline{2020}$

https://seputartuban.com/tuban-daruratcorona-bupati-tuban-buka-suara/ diakses tanggal 14 April 2020

https://palu.tribunnews.com/2020/03/25/bagai mana-cara-kerja-sabun-handsanitizer-mencegah-penyebaranvirus-corona diakses tanggal 13 April $\underline{2020}$

https://www.merdeka.com/peristiwa/sembilandaerah-di-jawa-timur-masih-zonamerah-covid-19.html diakses 10 Agustus 2020

https://surabaya.tribunnews.com/2020/07/24/ pemkab-tuban-targetkan-wilayahnyajadi-zona-kuning-pada-agustus-2020 diakses 11 Agustus 2020

Kusumayanti H., Paramita V., Wahyunimgsih, Amalia R., Siregar V.D., dan Pudiastuningtyas N. 2018. Pelatihan dan praktek pembuatan sabun cuci tangan cair di PKK Tembalang Pesona Asri. Gema Teknologi 20: 1

Weber DJ, Rutala WA (2006). "Use of germicides in the home and the healthcare setting: is there a relationship between germicide use and antibiotic resistance?". Infect Control Hosp Epidemiol. 27 (10): 1107-
19. doi: $\underline{10.1086 / 507964}$. PMID 17006 $\underline{819}$ 